\title{
CHEMICAL AND MICROBIOLOGICAL QUALITY OF PHYTOBIOTICS FROM BLENDS PLANT WITH DIFFERENT FERMENTATION RIPENING
}

\author{
Cahya Setya UTAMA ${ }^{\star 凶}$, Bambang SULISTIYANTO, and Sri SUMARSIH \\ Department of Animal Science, Faculty of Animal and Agricultural Sciences, Universitas Diponegoro. Jl. Prof. H. Soedarto, S.H, Semarang City, \\ Central Java 50275, Indonesia \\ Email: cahyasetyautama@gmail.com; (D) ORCiD: 0000-0002-95729579 \\ Supporting Information
}

\begin{abstract}
Alternative antibiotic replacements that are often used, namely probiotics, prebiotics, phytobiotics and acidifiers, have the same function and role as antibiotics. Phytobiotics are active ingredients that have antibacterial properties derived from herbal ingredients which newly used in human and animal nutrition, and this is new approach of nutritional studies. Fermentation process can improve the quality of phytobiotics. The purpose of the study was to examine the effect of fermentation time on $\mathrm{pH}$ values, organoleptic physical qualities, microorganism content and the content of phytobiotic fermentation with compounds namely: garlic (Allium sativum), Giloy (Tinospora cordifolia), leaf earring (Indian Acalypha), Indonesian bay-leaf (Syzygium polyanthum), betel leaf (Piper betle), ginger (Zingiber officinale), sand ginger (Kaempferia galanga), turmeric (Curcuma longa), galangal (Alpinia galanga), curcuma (Curcuma zanthorrhiza), temu ireng (Curcuma aeruginosa) and fruit waste. The study used a Complete Randomlzed Design (CRD) with 4 treatments; T0 (without fermentation), T1 (6-day fermentation), T2 (12-day fermentation), T3 (18-day fermentation). The results showed that the fermentation time of phytobiotics had a significant effect on pH, color, total Lactic Acid Bacteria (LAB), total bacteria, total fungi, gram+, gram-, antioxidant activity, total polyphenols and total acid. Phytibiotic fermentation time has no effect on the odor of fermented phytobiotics. In conclusion, Phytobiotic fermentation time of the best plant mixture is 12 days with a pH of 6.74, a total of Lactic Acid Bacteria (LAB) of $29.00 \times 103 \mathrm{cfu} / \mathrm{ml}$, total bacteria $22.2 \times 105$ $\mathrm{cfu} / \mathrm{ml}$, total fungi $0.6 \times 103 \mathrm{cfu} / \mathrm{ml}$ of antioxidant activity $45.33 \%$, total polyphenols $42.89 \mathrm{mg} / 100 \mathrm{ml}$ and total acid $0.18 \%$.
\end{abstract}

Keywords: Animal nutrition, Antioxidant, Fermentation, Phytobiotic, Polyphenols.

\section{INTRODUCTION}

The use of antibiotics in livestock has been banned in many countries (Aarestrup, 2012; Bacanlı and Başaran, 2019; Barkah et al., 2021). The use of antibiotics has negative effects such as bacterial resistance and the presence of residues on meat that are harmful when consumed (Bacanlı and Başaran, 2019; Sinurat et al., 2020). This makes poultry farmer's look for replacement materials that have the same function and role as antibiotics. Antibiotic substitutes that are often used are probiotics, prebiotics, phytobiotics and acidifiers (Ferdous et al., 2019). Phytobiotics are active ingredients that are antibacterial, derived from herbal ingredients and function to improve the digestive tract of livestock, increase the digestibility of food substances and improve livestock performance (Maksudi et al. 2018). Phytobiotics have relatively low side effects and work by affecting the nervous system, metabolism and increasing immune function (Drannikov et al., 2020).

One way to improve the quality of phytobiotics is the application of fermentation technology (Fresno Rueda et al., 2021; Ushakova et al., 2021). Fermentation can occur naturally in an ingredient, because the conditions are ideal for microorganisms to grow, and multiply (Carvalho et al., 2018). Fermentation is a biochemical process that can change the content of complex materials to be simpler, improve the quality of nutrients and improve the digestibility of the material (Chilton et al., 2015). Fermentation can also increase the active compounds in ingredients such as antioxidants (Kowalski et al., 2020). Polyphenols act as a source of enzymes in the fermentation process in the form of polyphenol oxidase enzymes (Burgos-Edwards et al., 2019).

Phytobiotic fermentation must be carried out at the right time and media, resulting in optimal quality of phytobiotic products. Fermentation results are strongly influenced by fermentation time because they are related to microbial activity (Utama and Christiyanto, 2021). If fermentation time be too long, it can produce very high level of lactic acid as the end product of metabolism, and result in changes in $\mathrm{pH}$, acidification of the material and failure of proton cytoplasm LAB, as well as impacting the failure of fermentation products (Othman et al., 2017). If fermentation time be too short, it can make microorganisms in breaking down materials not work optimally. Also fermentation processing affects antioxidant activity, total polyphenols and total acids (Dulf et al., 2016). Antioxidant activity is in correlation with total polyphenols 
during the fermentation process (Bei et al., 2020). The reshuffle of complex compounds into lactic acid by lactic acid bacteria with increasing fermentation time may lead to increased antioxidant activity and total amount of acid (Hur et al., 2014).

The purpose of the study was to examine the effect of fermentation time on $\mathrm{pH}$ values, organoleptic physical qualities, microorganism content and the content of fermented phytobiotic compounds. The benefit of research is to provide information about the effect of fermentation time on the $\mathrm{pH}$ value of organoleptic physical quality, microorganism content and the content of fermented phytobiotic compounds for using in dietary supplements in animal nutrition.

\section{MATERIALS AND METHODS}

\section{Materials}

The materials used in the study were garlic (Allium sativum), Giloy (Tinospora cordifolia), leaf earring (Indian Acalypha), Indonesian bay-leaf (Syzygium polyanthum), betel leaf (Piper betle), ginger (Zingiber officinale), sand ginger (Kaempferia galanga), turmeric (Curcuma longa), galangal (Alpinia galanga), curcuma (Curcuma zanthorrhiza), temu ireng (Curcuma aeruginosa),fruit waste, molasses, physiological saline solution $0.85 \%$, media de Man, Rogosa, Sharpe (MRS), Media Maximum Recovery Diluent (MRD, Merck, Germany), Media Dextrose Agar (MDA), Malt Extract Agar (MEA), aquadest, ethanol, $\mathrm{H}_{2} \mathrm{SO}_{4}, \mathrm{NaOH}$, and iodine solution. Tools used include copper vegetables, fermenters, platicin, colony counters, test tubes, petri dishes, incubators, pipettes, Whatman paper No. 41, analytical scales, bunsen, autoclave, Erlenmeyer and $\mathrm{pH}$ meter.

\section{Methods}

Research methods consist of phytobiotic manufacturing, research design, data retrieval and data analysis.

\section{Making fermented phytobiotics}

The manufacture of phytobiotics is done by weighing 12 ingredients consisting of garlic (Allium sativum), Giloy (Tinospora cordifolia), leaf earring (Indian Acalypha), Indonesian bay-leaf (Syzygium polyanthum), betel leaf (Piper betle), ginger (Zingiber officinale), sand ginger (Kaempferia galanga), turmeric (Curcuma longa), galangal (Alpinia galanga), curcuma (Curcuma zanthorrhiza), temu ireng (Curcuma aeruginosa), fruit waste of $1.5 \mathrm{~kg}$ each. All ingredients are cut in copper to a size of 1-2 cm, and mashed with a blender. All ingredients have been finely mixed until homogenous and added Lactobacillus casei and molasses. Phytobiotics are then weighed and divided into 20 equal parts and put into a fermenter and tightly closed with plasticine. The top of the fermentor tube is installed a hose, which serves as a way out of $\mathrm{CO}_{2}$ gas. The lid of the fermentor tube is re-wrapped with plasticine so as to create an anaerobic atmosphere. Phytobiotics are further fermented according to treatment $(0,6,12$ and 18 days).

\section{Research design}

The study used a completely randomized design (CRD) with 5 replications and 4 treatments. The treatment given is as follows: T0 = Phytobiotics without fermentation 0 days; T1 = Phytobiotics fermented for 6 days; T2 = Phytobiotics fermented for 12 days; T3 = Phytobiotics fermented for 18 days.

\section{Data retrieval}

The research parameters consisted of the value of potential of hydrogen $(\mathrm{pH})$, organoleptic physical quality, content of microorganisms and content of phytobiotic compounds.

\section{pH value test}

Testing pH (potential hydrogen) was done using a regular $\mathrm{pH}$ meter. The weighed sample was then homogenized using a mortar and added $20 \mathrm{ml}$ of distilled water. The homogeneous sample was then placed in a test glass and the $\mathrm{pH}$ was measured using a pH meter. The amount of $\mathrm{pH}$ is the reading of the $\mathrm{pH}$ needle after the needle is in constant position (Opsi et al., 2013).

\section{Organoleptic test}

Organoleptic testing was carried out using a scoring method, namely observing and assessing odor and color based on a comparison scale. Testing of organoleptic parameters was carried out by non-parametric analysis using the scoring method. The method in determining the quality level is based on a scale of 1 as the lowest value and 4 as the highest value using an assessment sheet (Utama and Christiyanto, 2021).

Odor assessment, 1: rotten, 2: odorless, 3: sour smell, 4: smell of spices.

Color assessment, 1: green, 2: yellowish green, 3: yellow, 4: brownish yellow.

\section{Microorganism content test}

Variable content of fermented phytobiotic microorganisms observed included total Lactic Acid Bacteria (LAB), total bacteria, total fungi, gram-positive bacteria, gram-negative bacteria and the percentage of bacteria based on their morphology (Stefańska et al., 2020). 


\section{Testing total lactic acid bacteria (LAB)}

LAB testing was carried out using the Total Plate Count (TPC) method. Phytobiotic samples were taken as much as 1 $\mathrm{ml}$ and put into a test tube. $9 \mathrm{ml}$ of $0.85 \%$ physiological saline solution was added to obtain a $10-1$ dilution of phytobiotics. $1 \mathrm{ml}$ of the sample from the $10-1$ dilution was taken and put into a test tube. $0.85 \%$ physiological saline solution was added again as much as $9 \mathrm{ml}$, in order to obtain a 10-2 dilution of phytobiotics, the dilution was carried out to 10-3. Petri dishes were prepared, and samples of the 10-3 dilution, were transferred to these petri dishes. Media de Man, Rogosa, Sharpe (MRS) agar, added to petri dishes. The cup and the sample were put into the incubator in an inverted position, and incubated at $37^{\circ} \mathrm{C}$ for 24 hours. The total LAB was then expressed in Colony Forming Units/gram (CFU/g), according to the procedure of Pramono et al. (2020).

\section{Total bacteria test}

The total bacteria test was carried out using the TPC method, which went through a dilution process such as the total LAB test, but was carried out until a phytobiotic sample was obtained at a dilution of 10-5. Media Maximum Recovery Diluent (MRD, Merck, Germany) agar was added to petri dishes and incubated for 72 hours at $30^{\circ} \mathrm{C}$. Total bacteria were counted with the help of a colony counter and expressed in units of CFU/g, according to Babacan (2021) procedure.

\section{Total fungi test}

The total fungus test was carried out using the TPC method, which went through a dilution process such as the total LAB test, until a sample of phytobiotics was obtained at a dilution of 10-3. Dextrose Agar (PDA) and Malt Extract Agar (MEA) media were added to petri dishes. Furthermore, sodium hypochlorite and $70 \%$ ethanol were added to prevent bacterial growth on the isolation media. Petri dishes and samples were then incubated at $37^{\circ} \mathrm{C}$ for 24 hours. Total fungi were expressed in units of CFU/g, according to the Bassem et al. (2020) procedure.

\section{Testing for gram positive (+) and gram negative bacteria (-)}

The test was carried out by the gram positive/negative staining method (Putri et al., 2012). Observations of grampositive and gram-negative bacteria were carried out under a microscope with 1000x magnification, observed for color and morphology. If the pink bacteria belong to the gram-negative group, process was continued according to Putri et al. (2012). The results of the identification of gram-positive and gram-negative bacteria were then tabulated and scored. The scores for the gram-positive bacteria used are;

Score $0=0$ (no) gram-positive bacteria in fermented phytobiotics

Score 1 = there is 1 gram positive bacteria in fermented phytobiotics

Score $\mathbf{2}$ = there are $\mathbf{2}$ gram-positive bacteria in fermented phytobiotics

Score $\mathbf{3}=$ there are $\mathbf{3}$ gram-positive bacteria in fermented phytobiotics

The scoring for gram negative bacteria used are;

Score $0=$ there are 3 gram negative bacteria in fermented phytobiotics

Score 1 = there are 2 gram negative bacteria in fermented phytobiotics

Score $\mathbf{2}=$ there is 1 gram negative bacteria in fermented phytobiotics

Score $3=0$ (no) gram-negative bacteria in fermented phytobiotics

The results of observations of gram positive and negative bacterial morphology under a microscope, combined according to bacterial morphology, and carried out calculations using the following formulas.

$$
\text { Bacterial Morphology }(\%)=\frac{\text { Number of Bacterial Morphology }}{\text { Number of Gram Positive Bacteria }+ \text { Gram Negative Bacteria }} \times 100 \%
$$

\section{Determination of antioxidant activity}

DPPH method (2-2-Diphenyl-1-Picrylhydrazyl) was used to determine the antioxidant activity of phytobiotics (Abramovič et al., 2018). The sample was weighed $98.4 \mathrm{~g}$ and then dissolved in $300 \mathrm{ml}$ of water. Samples were diluted with a concentration of $0-25 \mathrm{mg} / \mathrm{mL} .0 .2 \mathrm{~mL}$ of sample solution was put into a test tube with a lid. Added $3.8 \mathrm{~mL}$ of $50 \mathrm{~m}$ DPPH solution and homogenized with a vortex and allowed to stand for 30 minutes in a dark place and room temperature. The absorbance was measured on a UV-vis spectrophotometer at $515 \mathrm{~nm}$. Absorbance was calculated as \% of inhibition and determination of linear regression is then calculated the magnitude of IC 50 (ppm).

\section{Total polyphenol test}

Total polyphenol testing was carried out using the Folin-Ciocalteu Phenol method (Teixeira et al., 2018). The sample was weighed $98.4 \mathrm{~g}$ and then dissolved in $300 \mathrm{ml}$ of water. Samples were diluted with a concentration of 0-25 mg/mL. 1 $\mathrm{mL}$ of sample solution was put into a test tube with a lid. Added $7.8 \mathrm{~mL}$ of distilled water and $0.5 \mathrm{~mL}$ of Folin's reagent and allowed to stand for 8 minutes. The mixture was then added with $1 \mathrm{~mL}$ of $20 \%$ sodium carbonate and allowed to stand for 2 hours in a dark place and room temperature. The absorbance of the mixture was measured on a uv-vis spectrophotometer at $765 \mathrm{~nm}$. Absorbance was calculated the content of total polyphenols using gallic acid absorbance $(\mathrm{mg} / \mathrm{mL})$ as standard polyphenols to determine the linear regression equation. 


\section{Total acid test}

The total acid test was carried out by the titration method (Nielsen, 2004). Samples of $98.4 \mathrm{~g}$ were dissolved into 300 $\mathrm{ml}$ of distilled water to obtain a concentration of $328 \mathrm{mg} / \mathrm{ml} .10 \mathrm{ml}$ extract solution was put into $100 \mathrm{ml}$ Erlenmeyer then added 2 drops of Phenolphthalein indicator and homogenized with a vortex. Titrate filtrated with $0.1 \mathrm{M}$ sodium hydroxide solution until the color changes from clear to pink. The volume of sodium hydroxide is used to calculate the $\%$ total acid.

\section{Data analysis}

All data obtained were analyzed using the Analysis of Variance (ANOVA) test. If there was a significant effect, further testing is carried out using Duncan's Multiple Range Test (DMRT) at a 95\% confidence level.

\section{RESULTS AND DISCUSSION}

\section{pH and physical quality organoleptic}

The results of the study in Table 1 showed that there is a significant effect $(P<0.05)$ of different fermentation time treatments on $\mathrm{pH}$ and physical quality of fermented phytobiotic organoleptic. The results of the analysis showed that different fermentation time treatments affect the $\mathrm{pH}$ value of fermented phytobiotics. During phytobiotic fermentation there was a decrease in $\mathrm{pH}$ value as the fermentation time increases. Phytobiotic fermentation results from T0 - T3 obtained $\mathrm{pH}$ levels ranging from 6.18 - 7.01. The $\mathrm{pH}$ value was affected by the growth of lactic acid bacteria fermented products. Ripon et al. (2019) stated that the decrease in pH occurs due to the activity of microorganisms producing organic acids during the fermentation process. $\mathrm{pH}$ becomes one of the markers of successful or not fermentation process. Opsi et al. (2013) stated that good fermentation has a $\mathrm{pH}$ with acidic conditions.

The results of the variety analysis showed that the difference in fermentation time was not significant $(P>0.05)$ affecting the odor of fermented phytobiotics. The average organoleptic value of fermented phytobiotic odor was 4.00 . The value of 4.00 indicates that phytobiotics have a spice odor. The smell of spices from fermented phytobiotics comes from their constituent ingredients consisting of ingredients that are often used as herbs so as to produce the smell of spices. Gheisar and Kim (2017) stated that there is a smell of spices in phytobotics derived from their constituent ingredients. The absence of a typical smell of fermentation can be caused due to the strong odor of phytobiotic constituents. Utama and Christiyanto (2021) stated that the distinctive smell of fermentation arises due to the metabolic activity of microbes during the fermentation process. Phytobiotic odors are able to affect brain function by stimulating salivary glands and secretion of digestive enzymes (Stefańska et al., 2020).

The results of the variety analysis showed that the significant fermentation time difference $(P<0.05)$ affected the color of the fermentation phytobiotic. T0 was different from T1, T2 and T3; T1 was different from T2 and T3; T2 and T3 was no different from each other. The color of T0 was green, T1 was yellowish green and T2 and T3 were yellow. Fermented phytobiotics were brownish yellow because they are made from natural ingredients that tend to be yellow. Abd El-Ghany and Ismail (2014) stated that phytobiotics have constituent ingredients from natural ingredients that contain active ingredients. The occurrence of discoloration during the fermentation process from green to yellow, indicates a change in the temperature of fermentation. Rostini (2017) stated that temperature changes during the fermentation process can produce heat that can change the color of the material.

\begin{tabular}{|c|c|c|c|c|c|}
\hline $\begin{array}{l}\text { Treatment } \\
\text { Parameter }\end{array}$ & $\begin{array}{c}\text { TO (Without } \\
\text { fermentation) }\end{array}$ & $\begin{array}{c}\text { T1 (Fermented for } 6 \\
\text { days) }\end{array}$ & $\begin{array}{l}\text { T2 (Fermented for } \\
12 \text { days) }\end{array}$ & $\begin{array}{c}\text { T3 (Fermented for } \\
18 \text { days) }\end{array}$ & $\begin{array}{l}\text { P-Values } \\
(P<0.05)\end{array}$ \\
\hline $\mathrm{pH}$ & $7.01 \pm 0.04^{a}$ & $6.88 \pm 0.06^{b}$ & $6.74 \pm 0.07 c$ & $6.18 \pm 0.11^{d}$ & * \\
\hline Odor & 4.0 & 4.00 & 4.00 & 4.00 & NS \\
\hline Color & $1.00 \pm 0^{c}$ & $2.05 \pm 0.05^{b}$ & $3.00 \pm 0^{a}$ & $3.00 \pm 0^{a}$ & * \\
\hline
\end{tabular}

\section{Content of fermented phytobiotic microorganisms}

The results of Table 2 showed that there is a significant effect $(P<0.05)$ of different fermentation time treatments on the content of fermented phytobiotic microorganisms.

The results showed that the total Lactic Acid Bacteria (LAB) in T0 treatment was significantly different from T1, T2 and T3, while T1, T2 and T3 treatments were not significantly different from each other. Total LAB of fermented phytobiotics from highest to lowest were T2 (29.00 × $103 \mathrm{cfu} / \mathrm{g})$, T3 (20.60 × $103 \mathrm{cfu} / \mathrm{g}), \mathrm{T} 1$ (19.20 × $103 \mathrm{cfu} / \mathrm{g})$ and T0 $(2.60 \times 103 \mathrm{cfu} / \mathrm{g})$. The lowest total LAB was at TO which could occur because there was no fermentation process in this treatment. In the absence of a fermentation process, there is no large LAB activity, thus making the total LAB at TO lower than other treatments. Widyastuti and Febrisiantosa (2014) stated that LAB activity can occur during the fermentation process, namely the activity of converting sugar into lactic acid, acetic acid, ethanol and CO2. The total number of LAB 
which was not significantly different between T1, T2 and T3 treatments, could occur because the phytobiotics in that treatment provided a relatively the same substrate for LAB growth and development. The substrate is a source of nutrients for $L A B$ and the substrate is a medium for LAB to grow. Vuyst and Leroy (2020) stated that LAB species can live as long as the necessary nutrients are available, such as the presence of fructose as an energy source that can be fermented into lactic acid, even in the absence of co-substrates such as citric acid.

\begin{tabular}{|lccccc}
\multicolumn{7}{l}{ Table 2 - Content of fermented phytobiotic microorganisms from blends of plant with different fermentation ripening } \\
\hline Treatment & $\begin{array}{c}\text { T0 } \\
\text { (Without } \\
\text { fermentation) }\end{array}$ & $\begin{array}{c}\text { T1 } \\
\text { (Fermented for } \\
6 \text { days) }\end{array}$ & $\begin{array}{c}\text { T2 } \\
\text { (Fermented for } 12 \\
\text { days) }\end{array}$ & $\begin{array}{c}\text { T3 } \\
\text { (Fermented for 18 } \\
\text { days) }\end{array}$ & $\begin{array}{c}\text { P-Values } \\
\text { (P<0.05) }\end{array}$ \\
\hline Total LAB (CFU/g) & $2.60 \times 10^{3} \pm 0.12^{\mathrm{b}}$ & $19.20 \times 10^{3} \pm 0.35^{\mathrm{a}}$ & $29.00 \times 10^{3} \pm 0.45^{\mathrm{a}}$ & $20.60 \times 10^{3} \pm 0.58^{\mathrm{a}}$ & $*$ \\
Total bacteria (CFU/g) & $1.6 \times 10^{5} \pm 265.07^{\mathrm{c}}$ & $125.2 \times 10^{5} \pm 1162.52^{\mathrm{a}}$ & $22.2 \times 10^{5} \pm 359.59^{\mathrm{b}}$ & $28.40 \times 10^{5} \pm 434.58^{\mathrm{b}}$ & $*$ \\
Total fungi (CFU/g) & $0.6 \times 10^{3} \pm 15.15$ & $4.0 \times 10^{3} \pm 33.47$ & $0.6 \times 10^{3} \pm 15.15$ & $1.20 \times 10^{3} \pm 17.20$ & $\mathrm{NS}$ \\
Gram (+) & $2.20 \pm 0.40^{\mathrm{ab}}$ & $2.80 \pm 0.40^{\mathrm{a}}$ & $2.00 \pm 0^{\mathrm{b}}$ & $1.80 \pm 0.75^{\mathrm{b}}$ & $*$ \\
Gram (-) & $2.80 \pm 0.40^{\mathrm{a}}$ & $3.00 \pm 0^{\mathrm{a}}$ & $3.00 \pm 0^{\mathrm{a}}$ & $2.20 \pm 0.40^{\mathrm{b}}$ & $*$
\end{tabular}

Means on the same row with different super scripts are significantly $(P<0.05)$ different. NS: non-significant; *: $P<0.05 ;$ * $: P<0.01$.

Total fermented phytobiotic bacteria was influenced by fermentation time, T0 was significantly different from T1, T2 and T3; T1 was significantly different from T2 and T3; while T2 and T3 were not significantly different from each other. The total fermented phytobiotic bacteria from highest to lowest were T1 (125.2 × $105 \mathrm{cfu} / \mathrm{g})$, T3 (28.4 × $105 \mathrm{cfu} / \mathrm{g})$, T2 (22.2 $\times 105 \mathrm{cfu} / \mathrm{g})$ and TO (1.6 × $105 \mathrm{cfu} / \mathrm{g})$. Total bacteria at TO had the lowest number, because the total LAB (gram-positive bacteria) at TO was also the lowest. Total bacteria live on the material is consist of both gram-positive and gram-negative bacteria. Treatment T2 and T3 had a lower total number of bacteria than T1, this could be because the treatment was the optimal curing time, thus providing unsuitable conditions for the growth of gram-negative bacteria. Mani et al. (2017) stated that the lower bacterial population could occur due to an unsuitable environment for bacteria to survive. The highest total bacteria was in the T1 treatment, because the gram-negative bacteria were still high due to suboptimal curing. The curing that has not been optimal means that phytobiotic fermentation is also not optimal in reducing the number of gram-negative bacteria, so that when the total number of bacteria is calculated, it becomes the highest. Bao et al. (2018) stated that the total number of bacteria in the fermented material will be higher than the control treatment, and the total bacteria will increase at the beginning of the fermentation, then there will be a decrease until the end of the fermentation.

The total fermentable phytobiotic fungi was not affected by the fermentation time treatment. The total fermented phytobiotic fungi ranged from $0.6-4 \times 103 \mathrm{CFU} / \mathrm{g}$. minor level of total fungi can occur because in fermented phytobiotics there are bacteria, resulting in a competition and making the fungi unable to survive on phytobiotics. These bacteria are included in the LAB category. Siedler et al. (2018) stated that LAB produces various bioactive compounds that can inhibit fungal growth, with the mechanism of producing antifungal peptides produced during the proteolysis process. Organic compounds such as acetic acid produced from the breakdown of sugar by LAB, are also suspected to be the cause of the total fungus which is low in phytobiotics. Widyastuti and Febrisiantosa (2014) stated that the presence of bacterial activity in the material can affect antifungal activity, especially acetic acid, lactic acid and cyclo-(Leu-Pro) produced by bacteria, which act as antifungal compounds.

Different fermentation times affect the number of gram-positive bacteria fermented phytobiotics, with the scoring method carried out. The number of gram-positive phytobiotic bacteria at T1 was significantly different from T0, T2 and T3; while T0, T2 and T3 were not significantly different from each other. The number of gram-positive phytobiotic bacteria on

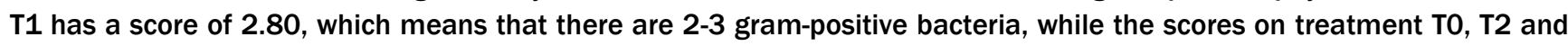
T3 are between 1.80 - 2.20, i.e. there are 1-2 gram-positive bacteria. Gram positive bacteria have thicker cell walls than gram negative bacteria. Domínguez et al. (2020) stated that gram-positive bacteria have thicker cell walls composed of negatively charged peptidoglycan, and the amount of peptidoglycan of gram-positive bacteria is more than that gramnegative bacteria. The higher number of gram-positive bacteria at $\mathrm{T} 1$, occurred because the curing carried out made the environmental conditions suitable for bacteria, so that the bacteria could anticipate oxidative stress. Imber et al. (2019) stated that most gram-positive bacteria such as Lactobacilli, Streptococci, Clostridia, and Listeria can produce Glutathione (GSH) in anticipation of enzyme metabolism regulation and oxidative stress, while gram-positive bacteria that do not produce GSH will utilize Low Molecular Weight (LMW) which is a peptide fraction as an alternative to overcome oxidative stress.

Different fermentation times affect the number of gram-negative bacteria fermented phytobiotics, with the scoring method carried out. The number of phytobiotic gram-negative bacteria at T3 was significantly different from T1, T2 and T3; while T0, T1 and T2 were not significantly different from each other. The number of phytobiotic gram-negative bacteria at T3 has a score of 2.20 , which means there is 1 gram-positive bacteria, while the scores in T0, T1 and T2 treatments are $2.80-3.00$, which means that there are no gram-negative bacteria. The lower number of gram-negative bacteria in T0, T1 
and T2 treatments was due to the presence of gram-positive bacteria that lived on phytobiotics, thus interfering with the presence of gram-negative bacteria. Zhang et al. (2018) stated that the decrease in the number of gram-negative bacteria can be caused by a tendency to increase the number of gram-positive bacteria, and the addition of nitrogen can increase the population of microorganisms in a material. As the length of time for phytobiotic curing at T3, the number of gramnegative bacteria increased. This is because the time for curing has been too long, and gram-positive bacteria enter the death phase. The reduced number of gram-positive bacteria causes the $\mathrm{pH}$ of the phytobiotic to increase and away from the acidic state, so that it becomes a potential place for the growth of gram-negative bacteria which results in an increase in the number of gram-negative bacteria. The T3 treatment which has a longer curing duration is inherent in the length of fermentation, the longer the fermentation, the increase in toxic gas that kills gram-positive bacteria and increases gramnegative bacteria. Huang et al. (2019) stated that high material humidity during fermentation can increase methane (CH4), and it can be higher with extended fermentation time.

The results of the study in Table 3 showed that the bacteria grow on phytobiotics consist of 4 morphology of gram positive bacteria and 1 morphology of gram negative bacteria.

Table 3 - Bacterial morphology growing on fermented phytobiotics from blends of plant with different fermentation ripening

\begin{tabular}{llcr} 
Types of Bacteria & Bacterial Morphology & $\mathbf{n}$ & (\%) \\
\hline Gram-positive & Solitary rod & 19 & 38.78 \\
Gram-positive & Spore stems lined up & 13 & 26.53 \\
Gram-positive & Coccus & 6 & 12.24 \\
Gram-positive & Yeast & 6 & 12.24 \\
Gram-negative & Solitary rod & 5 & 10.20 \\
Total & & 49 & 100 \\
\hline
\end{tabular}

The results of the observation of the morphology of gram-positive bacteria and gram-negative bacteria came from 5 bacterial morphologies. Four morphologies of gram-positive bacteria were found, among others, having a solitary rod morphology of 19 bacteria (38.78\%), spore rods lined up with 13 bacteria (26.53\%), coccus 6 bacteria (12.24\%), yeast 6 bacteria (12.24\%), and one gram-negative bacterium that had a solitary rod morphology was 5 bacteria (10.20\%). Solitary rod morphology is the most common morphology found in phytobiotics, both in gram-positive and gram-negative bacteria. Novitasari et al. (2019) states that bacteria can live in solitary (living alone/not in groups) and in colonies (clusters). The morphology of gram-positive bacteria with spore-lined rods is the morphology with the second highest number after solitary rods, which are found in phytobiotics. Bacterial morphology in phytobiotics can be precisely controlled by bacterial cells, which also play a role in maintaining cell shape, and can be determined by the geometry of the petidoglycan cell wall. Teeffelen and Renner (2018) stated that the common bacterial shape is rod and spherical shape, where shape plays an important role in growth, physiology, motility, invasion of the host and multicellularity of bacteria.

The number of gram bacteria that have a morphology of coccus and yeast has the same number, and is only found in gram positive bacteria. Bacteria with various morphologies can grow on phytobiotics due to the presence of a suitable environment for bacteria to live, such as organic matter and nutrients from the mixture of materials used. The bacterial morphology in the form of coccus observed was thought to come from the genus Bacillus sp. Prasetyawati et al. (2021) stated that Bacillus sp. It is round in shape, colonized and generally whitish cream in color. The form of bacteria in the form of yeast in fermented phytobiotics is a single-celled eukaryotic bacterium. Azhar et al. (2017) stated that yeasts are generally 1-10 m wide, have a high degree of nutrient selectivity and can utilize carbon sources for their survival. Based on the parameters of the content of microorganisms, the recommended treatment is T2, namely the fermentation time of phytobiotic fermentation for 12 days, because it has the highest total LAB descriptively, with a low total number of bacteria.

\section{Antioxidant activity, total polyphenols and total acid}

Based on the results presented in Table 4 there was a significant effect $(P<0.05)$ on different fermentation time treatments on antioxidant activity, total polyphenols and total acids fermented phytobiotic.

The results of the analysis of variance showed that the significant difference in curing time $(P<0.05)$ affected the antioxidant activity of fermented phytobiotics. T0 was significantly different from T1, T2 and T3; T1 was significantly different from T2 and T3; while T2 and T3 were not significantly different from each other. The value of antioxidant activity is influenced by $\mathrm{pH}$, temperature and the presence of secondary metabolic compounds. Gheisar and Kim (2017) stated that $\mathrm{pH}$ and temperature conditions can affect the antioxidant activity of phytobiotics. The value of oxidant activity increases with the length of curing. The highest antioxidant activity was obtained at T3 with $46.97 \%$. High and low antioxidant activity will affect the content of free radicals. Sembiring et al. (2018) stated that, antioxidant activity describes the ability of an antioxidant compound to inhibit the reaction rate of free radical formation. The presence of high free radicals in a feed ingredient will cause disturbances in livestock productivity (Panda and Cherina, 2013). 


\begin{tabular}{|c|c|c|c|c|c|}
\hline $\begin{array}{ll}\text { Parameter } & \text { Treatment }\end{array}$ & $\begin{array}{c}\text { TO (Without } \\
\text { fermentation) }\end{array}$ & $\begin{array}{l}\text { T1 (Fermented } \\
\text { for } 6 \text { days) }\end{array}$ & $\begin{array}{l}\text { T2 (Fermented } \\
\text { for } 12 \text { days) }\end{array}$ & $\begin{array}{l}\text { T3 (Fermented for } \\
18 \text { days) }\end{array}$ & $\begin{array}{l}\text { P Values } \\
(P<0.05)\end{array}$ \\
\hline Antioxidant Activities (\%) & $38.90 \pm 0.2^{b}$ & $24.23 \pm 0.4^{c}$ & $45.33 \pm 0.1^{a}$ & $46.97 \pm 0.2^{a}$ & * \\
\hline Total Polyphenols $(\mathrm{mg} / 100 \mathrm{ml})$ & $65.53 \pm 0.5^{a}$ & $39.29 \pm 0.3^{c}$ & $42.89 \pm 0.1^{b}$ & $46.39 \pm 0.1^{b}$ & * \\
\hline Total Acids (\%) & $0.60 \pm 0.04^{b}$ & $0.9 \pm 0.02^{a}$ & $0.18 \pm 0.03^{d}$ & $0.32 \pm 0 c$ & * \\
\hline
\end{tabular}

The results of the analysis showed that the significant difference in curing time $(P<0.05)$ affected the total fermentable phytobiotic polyphenols. T0 was significantly different from T1, T2 and T3; T1 was significantly different from T2 and T3; while T2 and T3 were not significantly different from each other. The highest total polyphenol value was at T0 with $65.53 \mathrm{mg} / 100 \mathrm{ml}$. During the fermentation process from T1-T3 there was an increase in total polyphenols. This can occur due to the hydrolysis of complex phenolics into simple phenols. (Haile and Kang, 2019) stated that in the fermentation process, proteolytic enzymes will hydrolyze complex phenolics into simple phenols so that they are easily absorbed. Polyphenols are antioxidants that can reduce cholesterol levels in meat through the activity of the Hidroxymethylglutaryl Coenxyme A Reductase (HMG-CoA) enzyme. Mo et al. (2012) stated that the activity of the HMGCoA enzyme would inhibit the production of mevalonate which is the basic compound of cholesterol.

The difference in fermentation time affects the total fermented phytobiotic acid. Total fermented phytobiotic acid at T0 was significantly different from T1, T2 and T3; T1 was significantly different from T2 and T3; while T2 and T3 were not significantly different from each other. The highest total acid value in T1 treatment (6 days fermentation time) was $0.9 \%$. The decrease in total acid value in T2 treatment was thought to be due to the cessation of lactic acid bacteria activity. The level of total acid is influenced by the activity of lactic acid bacteria during the fermentation process. Niamah et al. (2017) an increase in the population of lactic acid bacteria will also have an impact on increasing total acid. The increase in the total acid value during the fermentation process will affect the $\mathrm{pH}$. Total acid comes from the breakdown of glucose through the process of glycolysis into lactic acid. Tanguler and Erten (2012) stated that the final product of glucose fermentation through the Embden-Meyerhof-Parnas pathway is lactic acid.

\section{CONCLUSION}

In conclusion, the best time of phytobiotic fermentation of the blends plant (garlic, Giloy, leaf earring, Indonesian bay-leaf, betel leaf, ginger, sand ginger, turmeric, galangal, curcuma, temu ireng, and fruit waste) is 12 days with a pH value of 6.74 , total lactic acid bacteria $29.00 \times 103 \mathrm{cfu} / \mathrm{ml}$, total bacteria $22.2 \times 105 \mathrm{cfu} / \mathrm{ml}$, total fungus $0.6 \times 103 \mathrm{cfu} / \mathrm{ml}$ antioxidant activity $45.33 \%$, total polyphenols $42.89 \mathrm{mg} / 100 \mathrm{ml}$ and total acid $0.18 \%$. This formulation with this processing can be use as phytobiotics for livestock.

\section{DECLARATION}

\section{Acknowledgement}

Thanks for the Research Fund Grant for Lecturers of the Faculty of Animal and Agricultural Sciences, universitas diponegoro fiscal year 2021, which is contained in the decree of the Dean no. 36/UN7.5.5.2/PP/2021. Thanks also for the help of younger students; Nida Laili Manggarsari, Menkar Irwan Wicaksono, Ita Novitasari Gultom, Oktavianus Barus and Muhammad Fikri Haidar for their assistance in research activities and the preparation of activity reports.

\section{Author contribution}

CS.Utama collected the research data and wrote the scientific article. B.Sulistiyanto and S.Sumarsih contributed in data processing and writing of the scientific articles.

\section{Conflict of interests}

The authors declare that they have no competing interest.

\section{REFERENCES}

Aarestrup F (2012). Get pigs off antibiotics. Nature, 486: 465-466. DOI: https://doi.org/10.1038/486465a

Abd El-Ghany WA and Ismail M (2014). Tackling experimental colisepticaemia in broiler chickens using phytobiotic essential oils and antibiotic alone or in combination. Iranian Journal of Veterinary Research. 15(2): 110-115. DOI: https://dx.doi.org/10.22099/ijvr.2014.2341

Abramovič H, Grobin B, Ulrih NP, and Cigić B (2018). Relevance and standardization of in vitro antioxidant assays: ABTS, DPPH, and FolinCiocalteu. Journal of Chemistry, 2018: Article ID 4608405. DOI: https://doi.org/10.1155/2018/4608405

Azhar SHM, Abdulla R, Jambo SA, Marbawi H, Gansau JA, Faik AAM, and Rodrigues KF (2017). Yeasts in sustainable bioethanol production: A 
review. Biochemistry and Biophysics Reports, 10: 52-61. DOI: http://dx.doi.org/10.1016/j.bbrep.2017.03.003

Babacan 0 (2021). Determination of the presence and antibiotic resistance of listeria species and aerobic mesophilic bacteria count of cow milks. Veteriner Hekimler Derneği Dergisi, 92(1): 16-23. DOI: https://doi.org/10.33188/vetheder.714491

Bacanlı M, and Başaran N (2019). Importance of antibiotic residues in animal food. Food and Chemical Toxicology, 125: 462-466. DOI: https://doi.org/10.1016/i.fct.2019.01.033

Bao J, Zhang X, Zheng JH, Ren DF, and Lu J (2018). Mixed fermentation of Spirulina platensis with Lactobacillus plantarum and Bacillus subtilis by random-centroid optimization. Food Chemistry, 264: 64-72. DOI: https://doi.org/10.1016/j.foodchem.2018.05.027

Barkah NN, Wiryawan KG, Retnani Y, Wibawan WT, and Wina E, (2021). Physicochemical properties of products and waste of black seed produced by cold press method. IOP Conference Series: Earth and Environmental Science. 756(2021): 012025. D0I: https://doi.org/10.1088/1755-1315/756/1/0120250

Bassem A Balbool, Ahmed M Abdel-Azeem (2020). Diversity of the culturable endophytic fungi producing L-asparaginase in arid Sinai, Egypt. Italian Journal of Mycology, 49: 8-24. DOI: https://doi.org/10.6092/issn.2531-7342/10063

Bei Q, Wu Z, and Chen G (2020). Dynamic changes in the phenolic composition and antioxidant activity of oats during simultaneous hydrolysis and fermentation. Food chemistry, 305: 125269. DOI: https://doi.org/10.1016/i.foodchem.2019.125269

Burgos-Edwards A, Jiménez-Aspee F, Theoduloz C, and Schmeda-Hirschmann G (2018). Colonic fermentation of polyphenols from Chilean currants (Ribes spp.) and its effect on antioxidant capacity and metabolic syndrome-associated enzymes. Food chemistry, 258: 144-155. DOI: https://doi.org/10.1016/j.foodchem.2018.03.053

Carvalho MDC, Costa EM, Silva E, Pimentel L, Fernandes TH and Pintado ME (2018). Fermented foods and beverages in human diet and their influence on gut microbiota and health. Fermentation, 4(4): 1-13. DOl: https://doi.org/10.3390/fermentation4040090

Chilton SN, Burton JP and Reid G (2015). Inclusion of fermented foods in food guides around the world. Nutrients, 5(7): 390-404. D0I: https://dx.doi.org/10.3390\%2Fnu7010390

Domínguez AV, Algaba RA, Canturri AM, Villodres AR and Smani A (2020). Antibacterial activity of colloidal silver against gram-negative and gram-positive bacteria. Antibiotics (Basel), 9(36): 1-10. DOI: https://doi.org/10.3390/antibiotics9010036

Drannikov AV, Derkanosova AA, Korotaeva AA, Orinicheva AA, and Pribytkov AV (2020). Study of feed protein supplement with the properties of phytobiotics. IOP Conference Series: Earth and Environmental Science, 422: 012086. DOI: http://dx.doi.org/10.1088/1755$1315 / 422 / 1 / 012086$

Dulf FV, Vodnar DC, and Socaciu C (2016). Effects of solid-state fermentation with two filamentous fungi on the total phenolic contents, flavonoids, antioxidant activities and lipid fractions of plum fruit (Prunus domestica L.) by-products. Food chemistry, 209: 27-36. DOI: https://doi.org/10.1016/j.foodchem.2016.04.016

Ferdous MdF, Arefin MdS, Rahman MdM, Ripon MdMR, Rashid MdH, Sultana MstR, Hossain MT, Ahammad MU, Rafiq K (2019). Beneficial effects of probiotic and phytobiotic as growth promoter alternative to antibiotic for safe broiler production. Journal of Advanced Veterinary and Animal Research, 6(3): 409-415. DOI: https://doi.org/10.5455/javar.2019.f361

Fresno Rueda A, Samuel R, and St-Pierre B (2021). Investigating the Effects of a Phytobiotics-Based Product on the Fecal Bacterial Microbiome of Weaned Pigs. Animals, 11(7): 1950. DOI: https://doi.org/10.3390/ani11071950

Gheisar M, and Kim IH (2017). Phytobiotics in poultry and swine nutrition - a review. Italian Journal of Animal Science, 17(1): 92-99. DOI: https://doi.org/10.1080/1828051X.2017.1350120

Haile M and Kang WH (2019). Antioxidant activity, total polyphenol, flavonoid and tannin contents of fermented green coffee beans with selected yeasts. Fermentation. 5(29): 1-13. DOI: https://doi.org/10.3390/fermentation5010029

Huang X, Jiao J, Du J and Li Z (2019). Effects of different pre-processing methods on dry anaerobic fermentation of sugarcane leaves and pig manure. E3S Web of Conferences, 145(2065): 1-4. DOI: https://doi.org/10.1051/e3sconf/202014

Hur SJ, Lee SY, Kim Y-C, Choi I, and Kim G-B (2014). Effect of fermentation on the antioxidant activity in plant-based foods. Food Chemistry, 160, 346-356. DOI: https://doi.org/10.1016/j.foodchem.2014.03.112

Imber M, Pietrzyk-Brzezinska AJ and Antelmann H (2019). Redox regulation by reversible protein S-thiolation in gram-positive bacteria. Redox Biology, 20: 130-145. DOI: https://doi.org/10.1016/i.redox.2018.08.017

Kowalski R, Gustafson E, Carroll M and Meji EGD (2020). Enhancement of biological properties of blackcurrants by lactic acid fermentation and incorporation into yogurt: a review. Antioxidants, 9(12): 1-25. DOI: https://doi.org/10.3390/antiox9121194

Maksudi M, Manin F, Wigati S, and Insulistyawati A, (2018). Effects of Phytobiotic ofCurcuma aeruginosa, Curcuma longa and Zingiber officinale on the Performance and Carsass Qualityin Broiler. Jurnal IImiah IImu-llmu Peternakan. 21(2): 78-85. DOI : https://doi.org/10.22437/jiiip.v21i2.6772

Mani A, Ghosh A, Dey K and Bhattacharjee A (2017). Effect of sodium substitution on lactic acid bacteria and total bacterial population in lime pickle under ambient storage conditions. The Pharma Innovation Journal, 6(11): 682-686. DOI: https://www.researchgate.net/publication/321275603

Mo H, Yeganehjoo H, Shah A, Mo WK, Soelaiman IN and Shen, C.-L. (2012). Mevalonate-suppressive dietary isoprenoids for bone health. The Journal of Nutritional Biochemistry. 23(12): 1543-1551. DOI: https://doi.org/10.1016/j.jnutbio.2012.07.007

Niamah AK, Sahi AA, and Al-Sharifi ASN (2017). Effect of Feeding Soy Milk Fermented by Probiotic Bacteria on Some Blood Criteria and Weight of Experimental Animals. Probiotics \& Antimicrobial Proteins, 9(3), 284-291. DOI: https://doi.org/10.1007/s12602-017-9265-y

Nielsen S (2004). Food Analysis. Springer Science and Business Media, Springer US. Link: https://www.springer.com/gp/book/9781461425892

Novitasari C, Ramli M and Karyanto P (2019). Content analysis of misconceptions on bacteria in the biology textbook of high school. Journal of Physics: Conference Series, 1157 (2): 022076. DOI: https://doi.org/10.1088/1742-6596/1157/2/022076

Opsi F, Fortina R, Borreani G, Tabacco E, and López S (2013). Influence of cultivar, sowing date and maturity at harvest on yield, digestibility, rumen fermentation kinetics and estimated feeding value of maize silage. Journal of Agricultural Science, 151(5): 740-753. DOI: http://dx.doi.org/10.1017/S0021859612000925.

Othman M, Ariff AB, Solis LR and Halim M (2017). Extractive fermentation of lactic acid in lactic acid bacteria cultivation: a review. Frontiers in Microbiology, 8: 1-7. DOI: https://doi.org/10.3389/fmicb.2017.02285

Panda AK and Cherian G (2013). Role of Vitamin E in Counteracting Oxidative Stress in Poultry. The Journal of Poultry Science, 51(2): 109-117. DOI: https://doi.org/10.2141/ipsa.0130134

Pramono YP, Dwiloka NB, Mulyani S, Setiani BE, Rochmayani M and Bahtiar DE (2020). Utilization of lesser yam (Dioscorea esculenta L.) flour as prebiotic in yogurt to total lactic acid bacteria (LAB), sugar reduction, and organoleptic properties. Digital Press Life Sciences, 2(11): 1-10. DOI: https://doi.org/10.29037/digitalpress.22325 
Prasetyawati ET, Surtiningsih T, Ni'matuzahroh, Purkan, Silvia KS and Khiftiyah AM (2021). Exploration Indigenous Bacillus Bumiaji-Malang against Ralstonia solanacearum causing potato bacterial wilt. International Journal of Applied Biology, 5(1): 95-105. DOI: https://doi.org/10.20956/ijab.v5i(1).14184

Putri WDR, Haryadi MD and Cahyanto MN (2012). Isolation and characterization of amylolytic lactic acid bacteria during growol fermentation, an Indonesian traditional food. Journal of Agricultural Technology, 13(1): 52-60. Link: https://itp.ub.ac.id/index.php/itp/article/view/356

Ripon MMR, Rashid MH, Rahman MM, Ferdous MF, Arefin MS, Sani AA, Hossain MT, Ahammad MU, Rafiq K (2019). Dose-dependent response to phytobiotic supplementation in feed on growth, hematology, intestinal $\mathrm{pH}$, and gut bacterial load in broiler chicken Journal of Advanced Veterinary and Animal Research, 6(2): 253-259. DOI: https://doi.org/10.5455/javar.2019.f341.

Rostini T, (2017) Inoculan Differences in the Quality of Physical and Nutrition Quality Palm Fermentation Fronds as Animal Feed. IOSR Journal of Agriculture and Veterinary Science, 10(1): 29-32. Link: http://www.iosrjournals.org/iosr-javs/papers/Vol10-issue1/Version1/F1001012932.pdf

Sembiring BBR, Wiedosari E and Sujianto (2018). The effect of jamu formulas on body weight, antioxidant activities, and antibody titer in chicken. Jurnal Littri, 24(2): 65-74. DOI: http://dx.doi.org/10.21082/littri.

Siedler S, Balti R and Neves AR (2018). Bioprotective mechanisms of lactic acid bacteria against fungal spoilage of food. Current Opinion in Biotechnology, 56: 138-146. DOI: https://doi.org/10.1016/j.copbio.2018.11.015

Sinurat AP, Pasaribu T, Purwadaria T, Haryati T, Wina E, and Wardhani T (2020). Biological Evaluation of Some Plant Bioactives as Feed Additives to Replace Antibiotic Growth Promoters in Broiler Feeds. Indonesian Journal of Animal and Veterinary Sciences. 25 (2): 81-90. DOI: http://dx.doi.org/10.14334/jitv.v25i2.2501

Stefańska B, Sroka J, Katzer F, Goliński P, and Nowak W (2020). The effect of probiotics, phytobiotics and their combination as feed additives in the diet of dairy calves on performance, rumen fermentation and blood metabolites during the preweaning period. Animal Feed Science and Technology, 272: 114738. DOI: https://doi.org/10.1016/j.anifeedsci.2020.114738

Tanguler $\mathrm{H}$ and Erten $\mathrm{H}$ (2012). Occurrence and growth of lactic acid bacteria species during the fermentation of shalgam (salgam), a traditional Turkish fermented beverage. LWT - Food Science and Technology, 46 (1): 36-41. DOI: http://dx.doi.org/10.1016\%2Fj.Iwt.2011.10.026

Teeffelen SV and Lars DR (2018). Recent advances in understanding how rod-like bacteria stably maintain their cell shapes. F1000Research, 7(241): 1-12. DOI: https://doi.org/10.12688/f1000research.12663.1

Teixeira N, Mateus N, de Freitas V, and Oliveira J (2018). Wine industry by-product: Full polyphenolic characterization of grape stalks. Food Chemistry, 268: 110-117. DOI: https://doi.org/10.1016/j.foodchem.2018.06.070

Ushakova NA, Pravdin VG, Kravtsova LZ, Ponomarev SV, Gridina TS, Ponomareva EN, and Chikindas, ML (2021). Complex Bioactive Supplements for Aquaculture-Evolutionary Development of Probiotic Concepts. Probiotics and Antimicrobial Proteins, 2021: 1-13. DOI: https://doi.org/10.1007/s12602-021-09835-y

Utama CS and Christiyanto M (2021). The feasibility of fermented litter as a feed ingredient for ruminant livestock. Journal Of Advanced Veterinary And Animal Research. 8(2): 312-322. Dol: http://doi.org/10.5455/javar.2021.h517

Vuyst LD and Leroy $F(2020)$.Functional role of yeasts, lactic acid bacteria and acetic acid bacteria in cocoa fermentation processes. FEMS Microbiology Reviews, 44(4): 432-453. DOl: https://doi.org/10.1093/femsre/fuaa014

Widyastuti YR and Febrisiantosa A (2014). The role of lactic acid bacteria in milk fermentation. Food and Nutrition Sciences, 5(4): $435-442$. DOI: https://doi.org/10.4236/fns.2014.54051.

Zhang T, Chen HYH and Ruan H (2018). Global negative effects of nitrogen deposition on soil microbes. The ISME Journal, 12: 1817-1825. DOI: https://doi.org/10.1038/s41396-018-0096-y 